\title{
Creative Thinking of Low Academic Student Undergoing Search Solve Create and Share Learning Integrated with Metacognitive Strategy
}

\section{Yusnaeni}

Postgraduate Students, State University of Malang, Indonesia. Biology Education

Programme, University of Nusa Cendana Kupang, Indonesia

\author{
Aloysius Duran Corebima \\ Biology Department, Faculty of Mathematics and Natural Science, State University of \\ Malang, Indonesia, durancorebima@gmail.com
}

\section{Herawati Susilo}

Biology Department, Faculty of Mathematics and Natural Science, State University of Malang, Indonesia

\section{Siti Zubaidah}

Biology Department, Faculty of Mathematics and Science, State University of Malang, Indonesia

This research was carried out to analyze the effectiveness of the Search Solve Create and Share learning integrated with metakognitive strategy [SSCS + MS] on the creative thinking ability of low academic students. A quasi experimental design has been used to compare the effect of traditional learning, SSCS, and SCCS + MS learning on the creative thinking ability of tenth grade students in Kupang, Indonesia, conducted in three schools. The research data were analyzed by ANCOVA and Least Significant Different test. The results of the research showed that the SSCS + MS learning improved the creative thinking ability of the low academic students ability as much as $36.18 \%$ higher than that of the high academic students. These findings also showed that the SSCS + MS learning had the potential in improving the creative thinking ability of the low academic students, as well as the potential to equalize the low academic students and those of high academic ability. Teachers need to implement SSCS + MS learning because this learning can improve the student creative thinking ability especially of those of low academic ability. SSCS + MS learning uses problem solving so has the potential to empower student confident attitude.

Key Words: creative thinking, low academic, metacognitive strategy, SSCS, learning

Citation: Yusnaeni, Corebima, A. D., Susilo, H. \& Zubaidah, S. (2017). Creative Thinking of Low Academic Student Undergoing Search Solve Create and Share Learning Integrated with Metacognitive Strategy. International Journal of Instruction, 10(2), 245-262. https://doi.org/10.12973/iji.2017.10216a 


\section{INTRODUCTION}

The education condition in Indonesia still needs a lot of attention, especially related to the student recruitment system in schools, among others at senior high school level. Almost all schools in Indonesia used the recruitment system based on the Minimum Passing Level (MPL) of National Final Exam. The student recruitment based on such system makes some schools having students of high academic ability (top school category) and some schools having students of low academic ability only. For instance, the passing grade for Senior High School 1 Bekasi is 35.10 - 38.40, while the passing grade for Senior High School Bumi Saleh Bekasi is 20.05-32.15, Senior High School 1 Jakarta 32.80-38.25 and Senior High School 115 Jakarta 18.70-24.16 (BPS, 2015).

The polarization of students having high academic ability or low academic ability in a particular school will have an impact on different teachers' teaching patterns. This condition related to the numerous differences found on the students having high academic ability and those having low academic ability. Students of high academic ability have better learning orientation and learning habits (Sarwar et al., 2009), have a high need for achievement, have a hope for success, and have a higher persistence (Jabeen \& Khan, 2013), as well as show a better performance in completing problem solving tasks, and consequence test (Suman \& Umapathy, 2003; Ford \& Moore, 2013). Meanwhile, the students of low academic ability are often associated with failure in education (Marks, 2006).

Due to a significant difference between students having high academic ability and those having low academic ability, and the teacher's teaching patterns, the gap between students of high academic ability and those of low academic ability will be wider. Corebima (2007) stated that the gap between high academic ability students and low academic ability students should be taken into consideration, and it was expected that the gap becomes smaller in the learning process and learning results. Therefore, the efforts to minimize the gaps among students' based on academic ability need to be done so it can improve the learning quality and increase the potential of students' creative thinking abilities.

Creative thinking is a mental process involving cognitive processing (Beyer, 1987; Swart \& Perkinsn, 1990). Tan (2000), Hargrove (2013), and Greenstein (2012) revealed that creative thinking was one of the high-order thinking skills which was very important to be developed in the 21 st century. Creative thinking will produce creative generations having potency to solve complex social and environmental issues. Hotaman (2008) also revealed that creative thinking was the ability of making connection between the relations never made before and producing experiences new and original thoughts as a new pattern in a schema.

The students' creative thinking abilities which are different from one another require a learning condition involving a learning experience, so that the potential of creative thinking can develop. All students of different academic abilities can develop their creative thinking skills, if the learning environment provides an opportunity for the 
development of these thinking skills (Wheeler, 2002); Sternberg (2006) stated that learning environment was a necessary resource for creative thinking.

One of the efforts to develop the creative thinking skill is by creating a learning environment especially by involving students' real experience in learning. This effort can be achieved by implementing appropriate learning models. The effective learning model can minimize the gap between high academic ability students and those of low academic ability. Selecting the appropriate learning model will have an effect on improving their academic ability. Damavandi et al. (2011) revealed that students' ability could be improved by creating learning environment suitable with students' learning styles as well as by implementing flexible learning. Lince (2009) argued that creative thinking as a positive action was an important factor in stimulating brain function that could show and create a good learning style. Therefore, learning should be carried out using student-centered learning model, and one of which is Search Solve Create and Share [SSCS] learning model.

SSCS is one of the cooperative learning models based on problem solving (Awang and Ramly 2008; Pizzini \& Separdson, 1992). Chin (1997) reported that SSCS involved the students' learning experience and, developed critical thinking skills, questioning skills, thinking and sharing (Baroto 2009; Irwan, 2011; Johan, 2012). Haw Chen (2013) added that SSCS model helped students to develop advanced cognitive abilities such as creative thinking, problem solving and communication skills.

To improve the thinking skill, in addition to using a learning model, metacognitive strategy (MS) can also be implemented. Metacognitive strategies refer to the awereness of monitoring one's cognitive strategies to achieve specific goals. MS deals with the ways to improve the awareness about the thinking process and the learning that takes place (Flavel, 1981). MS in learning includes planning, observing, and assessing what is learned. According to Costa (1984) and Blakey and Spence (1990), several metacognitive strategies that could be used to develop thinking skills were planning, questioning, selecting consciously, evaluating the ways of thinking and acting, identifying problems, elaborating students' ideas, solving cooperative problem and modeling. In addition to these strategies, underlining, taking notes, summarizing, and concept mapping on reading materials while learning (Slavin, 1986), self-planning and self-assessing (Taccasu Project, 2008) are the strategies that can be used to improve the thinking skill.

The MS used in this research was underlining categorized as a monitoring strategy and self assessing which is classified as self-evaluation strategies. Simsek and Balaban (2010) and Weistein and Meyer (1986) revealed that underlining was one of the students' strategies in selecting the important ideas from books. The strategy of underlining a passage can monitor students' comprehension during the reading activity and optimize the information presented in the book. Riyadi (2012) reported that underlining could engage the students actively in constructing their knowledge. While self-assessing strategy was one type of students' self-assessment, in which the students were asked to assess themselves. According to Spiller (2012), self-assessing is the formative assessment process, where the students reflect and evaluate the quality of their 
work and learning as well as identify their strengths and weaknesses, and then revise it. Andrade and Valtcheva (2009) and Pintrich (2000) stated that self-assessing in learning could improve students' achievement and their self-regulation. Self-regulation is the tendency of a person to monitor and manage their own learning.

Some researches investigating the effect of metacognitive strategies on thinking ability have been reported by Maulana (2008), Miranda (2010). In general, their research results showed that the use of metacognitive strategies in learning could enhance students' thinking ability. Rahimirad and Zare-ee (2015) also reported that metacognitive strategies in learning could improve students' self-efficacy.

By the integration of SSCS and MS learning models those low academic students are expected to improve their learning quality and improve their thinking abilities, especially their creative thinking ability. Moreover, the gaps between the high and low academic ability students can be minimized, and learning results can increase. The results of this research are expected to be taken into considerations by teachers to implement SSCS + MS learning model to improve the learning results of the low academic students while waiting for the new student recruitment system no longer based on the MPL system. This study differs from Suciati (2013). In this study MS was carried out by adding underlining technique in the phase of search and self-assessing at the end of share phase.

\section{METHOD}

\section{Research Design}

This study was a quasi experimental research conducted by comparing the effectiveness of traditional learning, SSCS, and SCCS + MS learning models on the creative thinking ability of the tenth grade students in Kupang, Indonesia. The research design (Table 1) was pretest-posttest Nonequivalent control group design (Borg \& Gall, 1983).

Table 1

The experimental Design of Pretest - Potstest non equivalent control Group Design

\begin{tabular}{lll}
\hline Pretest & Treatment & Posttest \\
\hline T1 & M1A1 & T2 \\
\hline T3 & M2A1 & T4 \\
\hline T5 & M3A1 & T6 \\
\hline T7 & M1A2 & T8 \\
\hline T9 & M2A2 & T10 \\
\hline T11 & M3A2 & T12 \\
\hline
\end{tabular}

(Adapted from Borg \& Gall, 1983)

$\begin{array}{rlrl}\text { Note }: & \text { M1 }=\text { SSCS + MS learning model } & \mathrm{A} 1=\text { high academic ability } \\ \text { M2 = SSCS learning model } & \mathrm{A} 2=\text { low academic ability } \\ \text { M3 = Traditional learning } & \mathrm{T}_{2,} \mathrm{~T}_{4}, \mathrm{~T}_{6}, \mathrm{~T}_{8}, \mathrm{~T}_{10} \text { and } \mathrm{T}_{12} \text { posttest } \\ \mathrm{T}_{1}, \mathrm{~T}_{3}, \mathrm{~T}_{5}, \mathrm{~T}_{7}, \mathrm{~T}_{9} \text { and } \mathrm{T}_{11} \text { pretest } & \end{array}$




\section{Study Samples}

This research was conducted in three schools, namely state senior high school 3 Kupang, state senior high school 4 Kupang, and catholic senior high school of Giovanni Kupang. The sampling technique is total sampling based on the consideration that only three of the schools are available in Kupang. Three natural science classes of the tenth grade in the first semester of each school were involved in this study. The research samples consisted of students having homogeneous academic ability based on the placement test result. The high academic students and those of low academic ability were taken as much as $33.3 \%$ from each sample class (Suratno, 2010). The three classes were given an essay test developed by the researchers to measure the students' initial creative thinking ability before the treatments were brought about.

\section{Instruments}

The creative thinking ability was measured by essay test, consisting of ten numbers. The measurement of the creative thinking ability score was based of Treffinger et al. (2002) refering to five aspects of creative thinking. Essay tests were given at the beginning (pretest) and the end of the study (post-test). The used instruments were validated before by the expert and empirical validation. Expert validation consisted of content and construct validity. Content validity is the accuracy of an instrument in terms of the content of the instruments, estimated in accordance with the curriculum. Construct validity is related to contruction or science concept to be tested. Construct validity refers to the appropriateness of the results of the measuring instrument with ability to be measured. Empirical validity was conducted on 105 senior high schools students in Kupang, Indonesia. Reliability of the essay test was also examined. Reliability refers to degree of test score which are free from measurement error or an index that indicates the extent to which a measuring instrument is trustworthy or reliable. The reliability of the instrument is 0.71 having distinguishing power as much as $0.41-0.61$ and the difficulty level as much as $24.44 \%-60.56 \%$.

\section{Experimental Process}

The three classes of each school were taught by different learning style that is traditional learning, SSCS, and SCCS + MS learning models for one semester. The subject matter consisted of biodivesrsity, virus, protista and monera. The traditional learning was carried out by the teachers without the intervention from the researcher; the SSCS model used the syntax according to Pizzini and Separdson, (1992). SSCS + MS model (also using the same syntax of SSCS model) was carried out by adding the intervention of researcher in the form of underlining technique in the phase of search and self-assessing at the end of share phase.

\section{Data Analysis}

The research data were analyzed by using two way ANCOVA followed by post hoc test of Least Significant Different (LSD). All the assumption (normality and homogenity) of ANCOVA have been fulfilled. The normality test result (t-test) related to the scores of pretest is 1.527 and -0.715 (standart error of Skewness and standart error of Kurtosis); 
the normality test result (t-test) related to the scores of posttest is -0.284 and -1.957 (standart error of Skewness and standart error of Kurtosis). On the other hand the homogenity test result related to the scores of pretest is $1.192(\mathrm{p}=0.314)$; the homogenity test result related to the scores of posttest is $0.934(\mathrm{p}=0.460)$.

\section{FINDINGS}

The results of the Ancova test on the students' creative thinking ability are presented in Table 2. The results of the corrected mean of the creative thinking ability of the high and low academic ability students are presented in Table 3. Table 4 shows the corrected mean of the students' creative thinking abilities among the combination learning models and academic ability.

Tabel 2

The Result of the Ancova Test on Students creative Thinking Ability

\begin{tabular}{llrrr}
\hline \multicolumn{1}{c}{ Source } & $D f$ & Mean Square & \multicolumn{1}{c}{$F$} & \multicolumn{1}{c}{ Sig. } \\
\hline Creative Ability & 1 & 11268.789 & 113.825 & 0.000 \\
\hline Model & 2 & 22869.850 & 115.503 & 0.000 \\
\hline Academic Ability & 1 & 1648.170 & 16.648 & 0.000 \\
\hline Model * Academic Ability & 2 & 163.313 & 0.825 & 0.440 \\
\hline
\end{tabular}

Table 2 shows that the learning model and academic ability have an effect on students' creative thinking ( $\mathrm{p}<$ sig.0.05), but the interaction between the two factors did not show a significant effect ( $p>$ sig. 0.05). The results of the corrected mean of the creative thinking ability of the high and low academic ability students are presented in Table 3.

Table 3

The Results of corrected Mean of the creative Thinking Ability of the Students having high academic Ability and low academic Ability

\begin{tabular}{llllll}
\hline $\begin{array}{c}\text { Academic } \\
\text { Ability }\end{array}$ & $\begin{array}{c}\text { Pretest } \\
\text { creative } \\
\text { ability }\end{array}$ & $\begin{array}{c}\text { Posttest } \\
\text { creative } \\
\text { ability }\end{array}$ & Difference & $\begin{array}{c}\text { Corrected } \\
\text { creative }\end{array}$ & $\begin{array}{c}\text { Improvement } \\
(\%)\end{array}$ \\
\hline High & 22.27 & 57.01 & 34.73 & 60.24 & 170.50 \\
\hline Low & 28.22 & 69.37 & 41.14 & 66.17 & 134.48 \\
\hline
\end{tabular}

The corrected mean of the creative thinking ability of high and low academic ability students in Table 3 show that the high academic ability students are different from the low academic ability students, in that the score improvement of the low academic ability students was $21.13 \%$ higher than that of the high academic ability students. Table 4 shows the comparison of mean score of creative thinking ability for all classes viewed from their low and high academic. 
Table 4

The comparison of mean score of creative thinking ability for all classes viewed from their low and high academic

\begin{tabular}{|c|c|c|c|c|c|c|}
\hline Learning Models & Pretest & Posttest & Difference & Cor & Improvement (\%) & Notation \\
\hline Traditional low academic & 22,50 & 42,22 & 19,72 & 45,21 & 100,93 & $\mathrm{a}$ \\
\hline Traditional high academic & 26,39 & 54,58 & 28,19 & 53,37 & 102,24 & $\mathrm{~b}$ \\
\hline SSCS low academic & 23,55 & 63,16 & 39,61 & 65,10 & 176,05 & $\mathrm{c}$ \\
\hline SSCS high academic & 28,16 & 72,11 & 43,95 & 68,98 & 144,96 & c d \\
\hline SSCS+MS low academic & 20,77 & 65,64 & 44,87 & 70,49 & 239,38 & $\mathrm{~d}$ \\
\hline SSCS+MS high academic & 30,13 & 81,41 & 51,28 & 76,16 & 152,77 & $\mathrm{e}$ \\
\hline
\end{tabular}

The corrected mean showing the creative thinking ability for all classes in Table 4 related to the traditional learning model show that the creative thinking ability of the high and low academic ability students is different ( $a$ and b), but the high academic ability students show an increase of their ability 1,27\% higher than that of the low academic ability students. The opposite thing is happened related to the SSCS learning model and SSCS + MS learning model. Related to the SSCS learning model, though the LSD notation between the high academic ability and low academic ability students is not different ( $c$ and cd), the increase of the creative thinking ability of the low academic ability students is $17,66 \%$ higher than that of the high academic ability students. These results show that the low academic ability students can improve their creative thinking ability further, so that they have creative thinking ability equal to that of those of high academic ability. While related to the SSCS + MS learning model it is seen that the creative thinking ability of the high and low academic ability students is different ( $\mathrm{d}$ and $\mathrm{e}$ ); the improvement of the creative thinking ability of the low academic ability students is $36.18 \%$ higher than that of the high academic ability students. These results also show that the low academic ability students are not only able to match the high academic ability students, but also exceed them. The visualization of the improvement of the creative thinking ability of the high academic ability students and those of low academic ability on the three learning models can be seen in Figure 1.

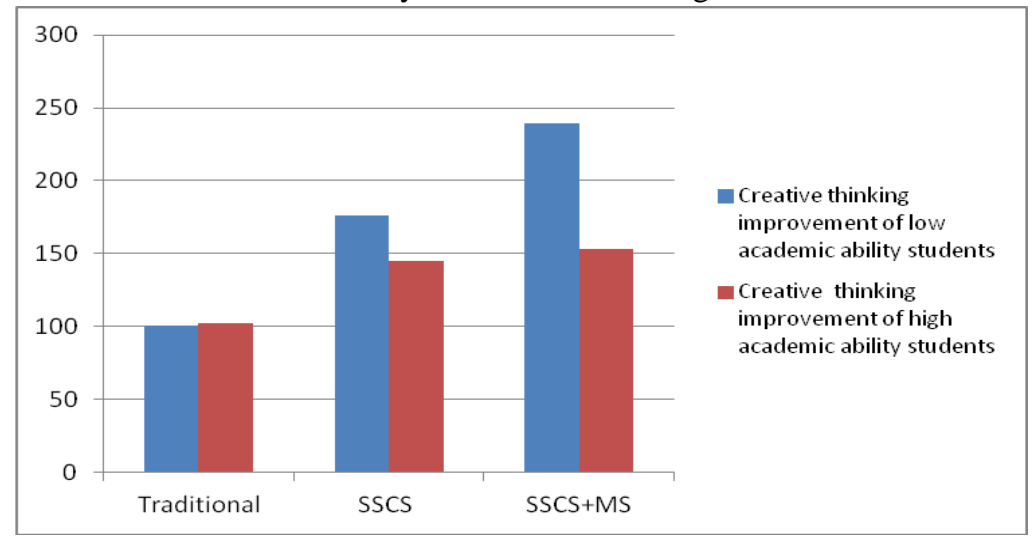

Figure 1. The graph of the creative thinking improvement of high and low academic ability students on traditional learning, SSCS and SSCS + MS learning models 


\section{DISCUSSION}

The results of the research show that the creative thinking ability of the low academic students experiencing SSCS + MS learning model increases, and even exceeds that of the high academic students. This means that the SSCS + MS learning model is potential in equalizing the creative thinking ability of the low academic students as well as of high academic students. These results are probably caused by of the metacognitive strategies involved in the SSCS + MS learning model. The integration of metacognitive strategies completes the advantages of the SSCS learning model. MS implemented in SSCS learning (SSCS+MS)gives students the opportunity to monitoring their learning and adapting as necessary. The students who are skillful in using their MS can understand their strengths and weaknesses during their learning. The students who are aware of their own strengths and weaknesses are expected to be able to control their own learning (self-regulated learning). According to Schunk (2008) self-regulated learning is the ability to control and to understand our own learning environment including selecting the best strategies that help to achieve our goal. Self-regulated learning can make the students become independent learners. According to Zumbrunn (2011), the students' quality as independent learners can be seen from their proactive and motivated attitude to voluntarily offer answers to questions, seek additional learning resources when needed, and easily manipulate the learning environment.

Collaborative activity and problem solving that become the characteristics of SSCS + MS learning model make the low academic students become self-conscious thinkers, which can be clearly seen in the phase of search and solve. Students can express ideas and solutions to any problems raised. Students' creativity are very prominent and various in the create phase although they raised the same problems. These results are in line with Wheeler's opinion (2002) saying that all students of different academic abilities can develop their creative thinking abilities, if the learning environment provides an opportunity for the development of these ideas. Purwanto (1997) also revealed that the thinking ability could be developed and enriched by enriching meaningful experiences in the learning process. In this research, collaboration and problem solving are a form of learning experience that can stimulate the creative thinking abilities of low academic ability students. The learning activity among the students of different academic abilities is potential in improving the thinking ability of the low academic ability students. According to Leisema \& Wannapiroon (2014), cooperative learning can strongly encourage the development of students' creative thinking abilities. While Blakey and Spence (1990) revealed that problem solving made the students more able to think actively.

The increase of the creative thinking ability of low academic ability students may not be separated from the role of metacognitive strategies given to them. Metacognitive strategies, especially underlining and self-assessing strategies have positive effect and more effective on low academic ability students. Giving an underlining on a reading passage can enhance their direct interaction with the subject matter, so that their learning process becomes more meaningful. In underlining activity, they not only read, but also involve the thinking process, to determine the important ideas in the reading materials to 
be underlined. Several advantages of underlining strategy is to make students learn more intensively (Dalyono, 1997), to make it easier to find information (Slavin, 1986) and to help students to construct their own knowledge (Hernowo, 2003). The statements from the three experts revealed the same effects in this research, especially for the low academic ability students.

Underlining is a monitoring strategy in learning, especially in relation to reading. If the underlining activity is continued and made it as a habit for the low academic ability students, their learning and thinking ability are predicted to be improved. Thus, what is revealed by Marks (2006) that low academic ability students are often associated with failure in learning will not happen. In addition to underlining activity, the other activity presumed be able to improve the quality of students' academic ability is the selfassessing activity.

Self-assessing for low academic ability students is strongly assumed to improve their creative thinking ability. This is probably caused by the potency of self-assessing that can foster self-awareness. The questions raised in self-assessing constantly monitor their learning activities, in this case, including the things that will be done, things that have been accomplished, and the things students need to do to improve their learning process. This monitoring activity is thought to be effective to foster their self-awareness. Low academic ability students have been able to do self introspection after they discover their strengths and weaknesses in learning, until finally they strive to improve their learning quality. Hariyati (2007) stated that self-assessing was a process where the students had the responsibility to assess and to reflect on their own learning results. Kartikawati (2013) reported that self-assessing could enhance students' self-regulation. Selfassessing helps to improve students' understanding and students' academic achievement (Duckworth et al., 2009). Self-assessing also can motivate students with a diversity of readiness, experience and background in learning (Spiller, 2012).

Self-reliance and self-awareness in learning of the low academic ability students grown through metacognitive strategies in SSCS + MS learning model may motivate them to become independent learners. The success of the low academic ability students to become independent learners depends on how they plan, control and evaluate their thinking to be better. Yusnaeni (2015) confirmed that independent learners realized their strengths and weaknesses in learning and tried to make themselves useful by exploring their potential. Pintrick (2000) added that independent learners were active and constructive; they tried to monitor, regulate, control and motivate their behaviors.

Independent learning help students to improve their thinking abilities including the creative thinking. According to Shanon and College (2008), teaching metacognitive strategies to the students can help them to direct their own learning more succesfully. Furthermore, Hargrove (2007) revealed that using some metacognitive strategies could help to develop students' thinking ability, to build their metacognitive skills as well as their creative thinking. Ibe (2009) and Carin (1993) also added that metacognitive strategies in learning could motivate students to raise their learning awareness, provided an opportunity to learn how to understand and to solve an issue, and to foster their creative thinking ability. 
To date, the main concern of learning in the classroom is how to motivate low academic ability students to be proactive and to be engaged in learning process. The provision of learning experience in the SSCS + MS learning model is believed having potential to sharpen the mental and to improve motivation of the low academic ability students. In the class taught by using SSCS + MS learning model, the low academic ability students demonstrate a change and progress in learning. The low academic ability students participate more actively in the group and show more confidence. This confidence is assumed to be the results of the metacognitive strategies that have been implemented. Metacognitive strategies make them aware of their weaknesses. However, their weaknesses can be overcome and repaired, so that it results in the improvement of their learning quality.

According to de Boer et al. (2013), metacognitive strategies are beneficial for the high academic ability students and low academic ability students. The difference in effectiveness between the students with different level of abilities is quite high. This research showed that the low academic ability students are very motivated with the implementation of the SSCS + MS learning model; the low academic ability students might show their creative thinking abilities. The teacher teaching strategies and students' learning styles have a very big role in making students as a self-conscious thinker and make them as independent learners. According to Corebima (2009), independent learners can be empowered or trained through specific strategies or effort. Furthermore it is explained too that the implementation of learning strategies such as self-regulation strategies can train students to talk to themself and to get them to constantly monitor and regulate their behavior. Therefore, in this research the low academic ability students can develop into independent learners and have an impact on improving their creative thinking ability when their learning environments are motivated by SSCS + MS learning model. The result of this research supports the findings of Chiu (1998) that metacognitive strategies are effective for low academic ability students and is in contrast to Hattie et al. (1996).

The results of this research also indicate that the learning in the classroom needs to consider the differences of students' academic abilities in order to know the effectiveness of the learning model used, because in this research, the low academic ability students learn more effectively with SSCS + MS learning model. Thus, as Sidi (2001) and Corebima (2007) said, differences in academic ability needed to be considered in learning, so that the gaps in the learning process and learning results could be minimized. The results of this research also support the statement of Sajedi \& Shafizadeh (2015), Pintrich (2002), and Al-Habaishi (2012) stating that the teacher's teaching strategy has a positive and significant correlation with the student's academic performance.

The results of this research are very useful to be implemented in schools or classes, because the majority of the students are those of the low academic ability students. In fact, there are still many schools in Indonesia whose students mostly have low academic ability. By implementing the SSCS + MS learning model in the classes, it is expected that the gap among the schools of different levels of ability can be minimized. 


\section{CONCLUSION}

Based on the research results it can be concluded that SSCS + MS learning model has the potential to improve the creative thinking ability of the low academic ability exceeding that of the high academic ability students. The improvement of the creative thinking ability of the low academic students in the SSCS + MS learning model is $36.18 \%$ higher than that of the high academic ability students. The SSCS + MS learning model improve the quality of learning in the classroom because it can foster awareness of learning and awareness of thinking of the low academic ability students. The SSCS + MS learning model is very useful to be implemented in schools because the majority of the students are those of the low academic ability students.

It is recommended that teachers implement SSCS + MS learning model in schools or classes that have low academic ability students. This learning model improves effectively the creative thinking ability of the low academic ability students.

\section{REFERENCES}

Al-Habaishi, S.M. (2012). Investigating the relationship between learning styles, strategies and the academic performance of Saudi English major. International Interdiciplinary Journal of Education, 1(8), 510-520.

Andrade, H., \& Valtcheva, A. (2009). Promoting learning and achievement through seflassessment. Theory into Practice, 48(1), 12-19.

Awang, H. \& Ramly, I. (2008). Creative thinking skill approach through problem based learning: pedagogy and practice in the engineering classroom. International Journal of Human and Science, 3(1), 18-23.

Baroto, G. (2009). Pengaruh model pembelajaran pbl dan model pembelajaran sscs ditinjau dari kreativitas dan intelegensi siswa [The Effect of PBL and SSCS learning model viewed from students' Creativity and Intelligence] (Unpublished thesis). Maret University.

Beyer, B. (1987). Practical strategies for the teaching of thinking. Boston: Allynannd Bacon Inc.

Blakey, E. \& Spence, S. (1990). Developing metacognition. ERIC Reproduction Services No ED327218. Retrived from http://www.eric.ed.gov/PDFS/ ED327218.pdf

Borg, W.L \& Gall, M.D. (1983). Educational research, an introduction. ( $4^{\text {th }}$ Ed.). Longman Inc: New York and London.

BPS. (2015). Bekasi dalam angka [Bekasi in Numbers]. BPS. Bekasi.

Carin, A.A. (1993). Teaching modern science. (6 $6^{\text {th }}$ Ed.). New York: Macmillan Publishing Co.

Chin, C. (1997). Promoting higher cognitive learning in science through a problem solving approach. REACT, 1, 7-11. 
Chiu, C.W.T. (1998). Synthesizing metacognitive interventions: What training characteristics can improve reading performance? Paper Presented at The Annual Meeting of the American Educational Research Association San Diego. C.A. April 1317, 1998 .

Corebima, A.D. (2007). Learning strategies having bigger potency to empowering thinking skill and concept gaining of lower academic student. Proceedings of Redesigning Pedagogy Conference. Nanyang. May 28-30, 2007.

Corebima, A.D. (2009). Jadikan peserta didik menjadi pebelajar mandiri [Make learners to be Independent learners]. Papers presented at UNM on December 19, 2009.

Costa, A.L. (1985). Teaching behavior that enable student thinking developing minds a source book for teaching thinking. Richmond: ASCD.

Dalyono, S. (1997). Psikologi pendidikan [Educational Psychology]. Jakarta: Rineka Cipta.

Damavandi, A. J., Mahyuddin, R., Elias, H., Daud, S.M., \& Shabani, J. (2011). Academic achievement of students with different learning styles. International Journal of Psychological Studies, 3(2), 186-192.

De Boer, H., Donker-Bergestra, A.S., \& Kostons, D.D.M.N. (2013). Effective strategies for self-regulated learning: A Meta-Analysis. Groningen: GIONS.

Duckworth, K., Akerman, R., MacGregor, A., Salter, E., \& Vorhaus, J. (2009). Self regulated learning: Literature review. London: Institute of Education University/IOE.

Flavel, J.H. (1981). Monitoring social cognitive enterprises: Something else that may develop in the area of social cognition. In J. H. Flavel \& L. Ross (eds), Social cognitive development: Frontiers and possible futures (pp. 272-278). New York: Cambridge University Press.

Ford, D. Y. \& J.L III. Moore. (2013). Understanding and reversing underachievement, low achievement, and achievement gap among high ability African American males in urban school contexts. Urban Rev, 45, 339-419.

Greenstein, L. (2012). Assesing skill $21^{\text {st }}$ century. a guide to evaluating mastery and authentic learning. New York: Crowin A SAGE Company.

Hargrove, R.A. (2013). Assessing the long-term impact of a metacognitive approach to creative skill development. International Journal Technol Des Educ. 23(3), 489-517: doi 10.1007/s10798-011-9200-6.

Hargrove, R.A. (2007). Creating creativity in the design Studio: Assessing the impact of metacognitive skill development on creative abilities. (Doctoral dissertation). North Carolina State University.

Hattie, J., Biggs, J., \& Purdie, N. (1996). Effects of learning skills interventions on student-learning: A meta-analysis. Review of Educational Research, 669, 9-136. 
Haw Chen,W. (2013). Applying problem-based learning model and creative design to conic-section teaching. International Journal of Education and Information Technologies, 3(7), 73-80.

Hernowo. (2003). Quantum reading: Cara cepat dan bermanfaat untuk merangsang munculnya potensi membaca [Quantum reading: Quick and useful ways to stimulate the reading potential]. Bandung: Mizan Learning Center.

Hotaman, D. (2008). The Examination of the basic skill levels of the students in accordance with the perceptions of teachers, parents and students. International Journal of Instruction, 1(2), 39-55.

Ibe, H.N. (2009). Metacognitive strategy on classroom participation and student achievement in senior secondary school scence classrooms. Science Education International, 20(1-2), 25-31.

Irwan. (2011). Pengaruh pendekatan problem posing model search, solve, create and share (SSCS) dalam upaya meningkatkan kemampuan penalaran matematis mahasiswa [The effect of problem posing model of search, solve, create and share/sscs in improving students' mathematical reasoning abilities]. Jurnal Penelitian Pendidikan, 12(1), 1-10.

Jabeen, S. \& M.A. Khan. (2013). A study on need achievement of high and low achievers. Journal of Educational and Practice, 4(4), 204-207.

Johan, H. (2012). Pengaruh search, solve, create and share (SSCS) problem solving untuk meningkatkan kemampuan mahasiswa dalam merumuskan dan memilih kriteria pemecahan masalah pada konsep listrik dinamis [The effect of search, solve, create and share (sscs) problem solving to improve students' ability in drawing and to select problem solving criteria in the concept of dynamic electricity]. Jurnal Exacta, 10(2), 140-142.

Kartikawati, E. (2013). Pengembangan assessment formatif untuk meningkatkan habits of mind dan penguasaan konsep mahasiswa pendidikan biologi [Developing formative assessment to improve habits of mind and concept mastery of biology education students] (Thesis). Universitas Pendidikan Indonesia

Lince, R. (2016). Creative thinking ability to increase student mathematical of junior high school by applying models numbered heads together. Journal of Education and Practice, 7(6), 206-212.

Marks, G.N. (2006). Influences on, and the consequences of low achievements. The Australian Educational Researcher, 33(1), 95-115.

Maulana. (2008). Pendekatan metakognitif sebagai alternatif pembelajaran matematika untuk meningkatkan kemampuan berpikir kritis mahasiswa PGSD [Metacognitive approach as a mathematics learning alternative to enhance the critical thinking skills of elementary school teacher education students]. Jurnal Pendidikan Dasar, 2(10), 1-8. 
Miranda, Y. (2010). Dampak pembelajaran metakognitif dengan strategi koperatif terhadap kemampuan metakognitif siswa dana mata pelajaran biologi di sma palangka raya [The effect of metacognitive learning using cooperative strategy on students' metacognitive skill in biology subject of senior high school in Palangkaraya]. Jurnal Penelitian Kependidikan, 2(2), 187-201.

Pintrich, P.R. (2000). The role of metacognitive knowledge in learning, teaching and assessing. Teory into Practice, 41(4), 219-225.

Pizzini, E.L., \& Separdson, D.P. (1992). A comparison of the classroom dynamics of a problem solving and traditional laboratory model of instruction using path analysis. Journal of Research in Science Teaching, 29(3), 243-258.

Purwanto, G. (2007). Psikologi pendidikan [Educational psychology]. Bandung: PT Rosda Karya.

Rahimirad, M. \& Zare-ee, A. (2015). Metacognitive strategy instruction as a means to improve listening self-efficacy among irania undergraduate learners of English. International Journal of Instruction, 8(1), 117-132.

Riyadi, I. (2012). Strategi belajar metakognisi untuk meningkatkan kompetensi siswa pada mata pelajaran IPS [Metacognition learning strategy to improve students' competency in social science subject]. Jurnal Magistra, 24(82), 28-36.

Sajedi, R., \& Hamid, S. (2015). A study of relationship between learning strategy, achievement, motivation and academic performance among the student of Semnan university of medical science. International Journal Review Life Society, 5(4), 268-276.

Sarwar, M., Bashir, M., et al. (2009). Study orientation of high and low level achievers at secondary level in Pakistan. Educational Research and Review, 4(4), 44-47.

Schunk, D.H., (2008). Metacognition, self-regulation, and self-regulated learning: Research recomendation. Educational Psychology Review, 20(4), 463-467.

Shanon, S.V., \& College, W.S. (2008). Using metacognitive strategies and learning styles to create self-directed learners. Institute for Learning Styles Journal, 1, 14-28.

Sidi, I.D. (2001). Menuju masyarakat belajar: Menggagas paradigma baru pendidikan [Towards learning society: Initiating new paradigm of education]. Jakarta: Logos Wacana Ilmu.

Simsek, A., \& Balaban, J. (2010). Learning strategies of successful and unsuccessful university student. Contemporary Educational Technology, 1(1), 36-45.

Slavin, R.E. (1986). Education psychology. Theory and practice. (4 th Ed.). New York: Paramount Publishing.

Slavin, R.E. (2001). Cooperative learning: Theory, research, and practice. London: Allimand Bacon. 
Spiller, D. (2012). Assessment matters: Self-assessment and peer assessment. Wahanga: The University of Waikato.

Sternberg, R.J. (2006). The nature of creativity. Creativity research journal, 18(1), 8798.

Suciati, N. (2013). Pengaruh pembelajaran search, solve, create dan share dengan strategi metakognitif terhadap kemampuan menyelesaikan masalah dan berpikir kritis siswa [The effect of search, solve, create and share learning supported by metacognitive strategies on problem solving skills and critical thinking of students]. Jurnal Pendidikan Sains, 1(2), 194-200.

Suman, L.N., \& Umapathy, A. (2003). Parent child relationship and achievement motivation. Indian Psychological Rev, 36, 20-27.

Suratno. (2010). Memberdayakan keterampilan metakognisi siswa dengan strategi pembelajaran jigsaw reciprocal teaching (JIRAT) [Empowering of metacognition skills by learning strategy of jigsaw reciprocal teaching (JIRAT)]. Jurnal Ilmu Pendidikan, $17(2), 150-156$.

Taccasu project. (2008). Metacognition. Retrived April 20th, 2016 from http://www.hku.hk/cepc/taccasu/ ref/metacognition.htm.

Tan, A.G. (2000). A review of the study creativity in Singapore. Journal of Creative Behaviour, 34(4), 259-284.

Treffinger, D.J., Young, G.C., Selby, E.C., \& Shepardson, C. (2002). Assessing creativity: A guide for educator. Center for creative learning. Florda: Sarasota.

Weistein, C.E. \& Meyer, R. (1986). The teaching of learning strategies. In M.C. Wittrock (Ed.). Handbook of Research on Teaching. pp 315-327. New York: Macmillan.

Yusnaeni. (2015). Strategi metakognitif: Strategi menjadi pebelajar mandiri [Metacognitive strategy: Strategy to be independent learners]. Prosiding Seminar Nasional Pendidikan Biologi dan Sains Biologi. 47-56.

Zumbrunn, S. (2011). Enchouraging self-regulated learning in the Classroom: A review of the literature. Metropolitan Educational Research Consortium (MERC). Virginia Commenwealth University. 


\section{Turkish Abstract \\ Düşük Akademik Başarıya Sahip Öğrecilerin Yaratıcı Düşünmelerini Bilişötesi Stratejilerle Bütünleştirilmiş Öğrenmeyle Araştırma Çözme Yaratma ve Paylaşma}

$\mathrm{Bu}$ araştırma düşük akademik başarıya sahip öğrencilerin bilişötesi stratejilerle (SSCS+MS) bütünleştirilmiş araştırma, çözme, yaratma ve paylaşma öğrenmelerinin etkililiğinin analizini gerçekleștirmiştir. Endonezya Kupang'daki üç okuldaki 10. sınıf öğrencilerinin Klasik öğrenme ve SSCS, ve SSCS+MS ile yaratıcı düşünme becerilerini karşılaştırmak için yarı deneysel yöntem kullanılmıştır. Araştırma verileri, ANNOva ve Anlamsal Farklılık Testi ile analiz edilmiştir. Araştırma sonuçları SSCS+MS öğrenme düșük akademik başarıya sahip öğrencilerin yaratıcı düşünmelerini yüksek akademik başarıya sahip öğrencilere göre $\% 36,18$ arttırmıştır. Bulgular ayrıca SSC+MS öğrenmenin düşük akademik başarıya sahip öğrencilerin yaratıcı düşünme becerilerini geliştirdiğini ve yüksek akademik başarıya sahip öğrencilerle aynı seviyeye ulaşma potansiyellerini arttırdığını göstermiştir.

Anahtar Kelimeler: yaratıcı düşünme, düşük akademik başarı, bilişötesi strateji, SSCS öğrenme

\section{French Abstract \\ Pensée Créative d'Étudiant Universitaire Bas Subissant Recherche Résout Créent et Part(Action) Apprenant Intégré avec Stratégie Metacognitive}

Cette recherche a été effectuée pour analyser l'efficacité de la Recherche Résolvent Créent et la Part(l'Action) apprenant intégré avec la stratégie metakognitive [SSCS + MME] sur la capacité pensante créative d'étudiants universitaires bas. Un design(une conception) expérimental quasi a été utilisé pour comparer l'effet d'apprentissage traditionnel, SSCS et SCCS + MME apprenant sur la capacité pensante créative d'étudiants de seconde(de dixième année) dans Kupang, l'Indonésie, conduite à trois écoles. Les données de recherche ont été analysées par ANCOVA et le test Différent le Moins significatif. Les résultats de la recherche ont montré que le SSCS + le MS apprenant améliorés la capacité pensant créative de la capacité d'étudiants universitaire basse bien $36.18 \%$ plus haut que celui des hauts étudiants universitaires. Ces conclusions ont aussi montré que le SSCS + le MS apprenant avait le potentiel dans l'amélioration de la capacité pensant créative des étudiants universitaires bas, aussi bien que le potentiel pour égaliser les étudiants universitaires bas et ceux de haute capacité universitaire.

Mots Clés: pensée créative, universitaire bas, metacognitive stratégie, SSCS, apprentissage

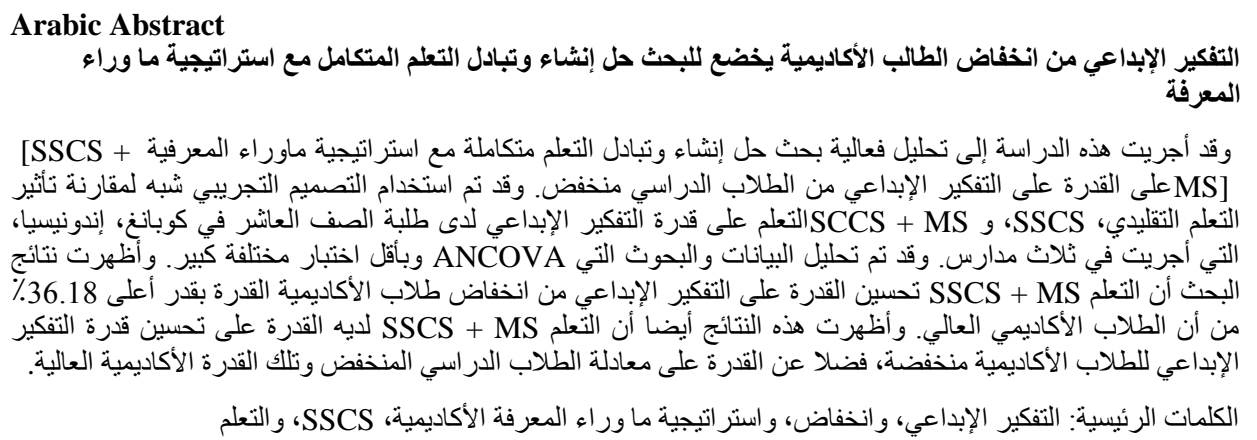




\begin{abstract}
German Abstract
Kreatives Denken von niedrigen akademischen Studenten, die sich durchsuchen, lösen und teilen Lernen integriert mit Metakognitiver Strategie

Diese Forschung wurde durchgeführt, um die Wirksamkeit der Suche lösen Lernen, die mit der metakognitiven Strategie [SSCS + MS] über die kreative Denkfähigkeit von Studierenden mit niedrigem akademischem Studium integriert wurde. Ein quasi experimentelles Design wurde verwendet, um die Wirkung von traditionellem Lernen, SSCS und SCCS + MS Lernen auf die kreative Denkfähigkeit der zehnten Klasse Studenten in Kupang, Indonesien, in drei Schulen durchgeführt $\mathrm{zu}$ vergleichen. Die Forschungsdaten wurden durch ANCOVA und Least Significant Different Test analysiert. Die Ergebnisse der Forschung zeigten, dass das SSCS + MS Lernen die kreative Denkfähigkeit der Studierenden mit niedrigem akademischem Studium so viel wie $36,18 \%$ höher als die der hohen akademischen Studenten verbesserte. Diese Erkenntnisse zeigten auch, dass das SSCS + MS-Lernen das Potenzial zur Verbesserung der kreativen Denkfähigkeit der niederen akademischen Studenten sowie das Potenzial hatte, die niedrigen akademischen Studenten und die mit hohem akademischem Können auszugleichen.
\end{abstract}

Schlüsselwörter: kreatives Denken, niedrige akademische, metakognitive Strategie, SSCS,Lernen

\author{
Malaysian Abstract \\ Pemikiran kreatif Pelajar Rendah Akademik Menjalani Carian Mencipta Penyelesaian dan \\ Perkongsian Pembelajaran Bersepadu dengan Strategi Metakognitif
}

Kajian ini telah dijalankan untuk menganalisis keberkesanan Carian mencipta penyelesaian dan perkongsian pembelajaran bersepadu dengan strategi metakognitive [SSCS + MS] pada keupayaan pemikiran kreatif pelajar akademik yang rendah. Satu reka bentuk kuasi eksperimen telah digunakan untuk melihat kesan pembelajaran tradisional, SSCS dan SCCS + MS pembelajaran kepada keupayaan kreatif pemikiran pelajar gred sepuluh di Kupang, Indonesia, yang dijalankan di tiga buah sekolah. Data kajian dianalisis dengan ujian ANCOVA. Keputusan kajian menunjukkan bahawa pembelajaran SSCS + MS meningkat keupayaan pemikiran kreatif keupayaan pelajar akademik yang rendah sebanyak $36.18 \%$ lebih tinggi berbanding pelajar akademik yang tinggi. Penemuan ini juga menunjukkan bahawa pembelajaran SSCS + MS berpotensi dalam meningkatkan keupayaan kreatif pemikiran pelajar akademik yang rendah, serta potensi untuk menyamakan pelajar akademik yang rendah dan mereka yang mempunyai pencapaian akademik yang tinggi.

Kata Kunci: pemikiran kreatif, rendah akademik, strategi metakognitif, SSCS, pembelajaran

\title{
Russian Abstract
}

Анализ Деятельности По Поиску, Обучению, Созданию и Распространению, Интегрированной с Метакогнитивной Стратегией в Отношении Навыков Творческого Мышления Учащихся с Низкой Успеваемостью

Это исследование было проведено с целью анализа эффективности решения поиск решить создать и поделиться обучением интегрированным с метакогнитивной стратегией (SSCS + MS) на способность творческого мышления учащихся с низким уровнем образования. 
Квази-экспериментальный дизайн был использован для сравнения влияния традиционного обучения, SSCS и SCCS + MS на способность творческого мышления 3 из 3 учащихся десятого класса в Купанге, Индонезия, проведенных в трех школах. Данные исследования были проанализированы ANCOVA и Least Significant Different тест. Результаты исследования показали, что sscs + ms-обучение улучшило способность креативного мышления у студентов, с низким уровнем образования, что на $36,18 \%$ выше, чем у студентов, с высоким уровнем образования. Эти результаты также показали, что обучение SSCS + MS имело потенциал в улучшении способностей творческого мышления студентов с низким академическим уровнем, а также в возможности уравнять студентов с низким и высокими уровнями образования.

Ключевые Слова: творческое мышление, низкий уровень образования, метакогнитивная стратегия, SSCS, обучение 